\title{
ARMENIANS OF RUSSIA: GEO-DEMOGRAPHIC TRENDS OF THE PAST, MODERN REALITIES AND PROSPECTS
}

\section{SERGEIY SUSHCHIY}

\begin{abstract}
The article analyzes the quantitative growth, spatial dynamics, gender structure and form of resettlement of the Armenian population of Russia in the 18th-20th centuries. The demographic correlation of the largest regional communities at different stages of their development are studied, and the main historical periods of the geo-demographic dynamics of the Armenians of Russia are determined.

The first stage can be designated as "South Russian" (second third of the 18th century - 1920s). At this time, the overwhelming majority of the Armenian population of Russia was concentrated within the southern macroregion. In the second stage (mid-1920s - first half of the 1980s), Armenians resettled almost throughout the entire territory of the RSFSR, but represented internally weakly connected ethnic groups. The third period (the second half of the 1980s - the present) is associated with the transformation of these groups into developed regional communities.
\end{abstract}

Three centuries of quantitative growth allowed Armenians to become one of the largest ethnic groups in the Russian Federation by the beginning of the 21st century. In the medium term (by 2030), with a favorable scenario of demographic dynamics, Armenians will be able to take the third position in the demographic ranking of the peoples of Russia (after the Russians and Tatars).

Key words: geo-demographic dynamics, Armenian population of Russia, regional diasporas, migration processes, resettlement system, gender balance.

Given the historically changing dynamics of the territorial limits of the Russian state, we will consider the geodemographic dynamics of the Armenian population within the spatial boundaries of the modern Russian Federation (as of 2018). Thus, we exclude from this study the analysis of the large centers of Armenians that existed not only within the Armenian or two other Transcaucasian republics, but also within all the other republics of the former USSR, as well as in a number of regions that were part of the Russian Empire until 1917. In some cases (specified in the text), however, we will talk about the entire Armenian population of the country, be it the Russian Empire or the Soviet Union. At the same time, by "the South of Russia" (the southern macroregion) we will understand the areas of the Don region, the lower Volga region, the steppe of the Pre-Caucasus, the North Caucasus and the Crimea, i.e. the territories currently constituting the two federal districts of the South and North Caucasus.

Individual immigrants from Armenia or local groups of its natives appear within the limits of the future Russia in antiquity and the Middle Ages. But only beginning with the incorporation into the Russian state of the lower Volga region (mid-16th century) do centers with large Armenian communities appear within the country (above all in Astrakhan, where Armenians had long resided). The number of such centers increases markedly in the 18th century, when a new Russian macroregion begins to form on the annexed lands of the Pre-Caucasus steppe.

SERGeiy SuSHChiy (SS7707@mail.ru), SOUTHERn SCIENTIFIC CENTER OF THE RUSSIAN ACADEMy OF SCIENCES, RUSSIA.

THE ORIGINAL ARTICLE IN RUSSIAN WAS PUBLISHED IN DEMOGRAPHIC REVIEW IN 2018, 5(3), 127-152. DOI: 10.17323/DEMREVIEW.V5I3.8138

THE ARTICLE WAS WRITTEN WITHIN THE FRAMEWORK OF THE PROJECT OF THE RUSSIAN FOUNDATION FOR BASIC RESEARCH "THE ARMENIAN COMMUNITY OF THE DON IN THE NEWEST PERIOD: HISTORY, INSTITUTIONS, IDENTITY" (18-59-05004). 
Armenian migrations organized (or encouraged) by the authorities at this time lay the foundations of a settlement network within the South of Russia. Starting in the second half of the century, the largest of these settlements become centers of attraction and concentration of new groups of immigrants. The specific composition of the focal points of the Armenian presence in the southern macroregion changes quite significantly. While in the $16^{\text {th }}-17^{\text {th }}$ centuries the main centers of Armenians are Astrakhan, Derbent, and the Adygo-Cherkessky mountain range in the Northwest Caucasus, in the mid-late $18^{\text {th }}$ century the lower Don River (Nor-Nakhichevan with the adjacent Armenian villages) and the districts of Kizlyar and Mozdok also become significant. In total, the Armenian population of the South of Russia at the turn of the $19^{\text {th }}$ century is about $23-$ 24 thousand people (without the Cherkessogai, who, if included, could increase this number to 30 35 thousand). The southern macroregion accounts for up to 98-99\% of the Armenian population of the whole of Russia, and for a long time it becomes their main center (Figure 1).

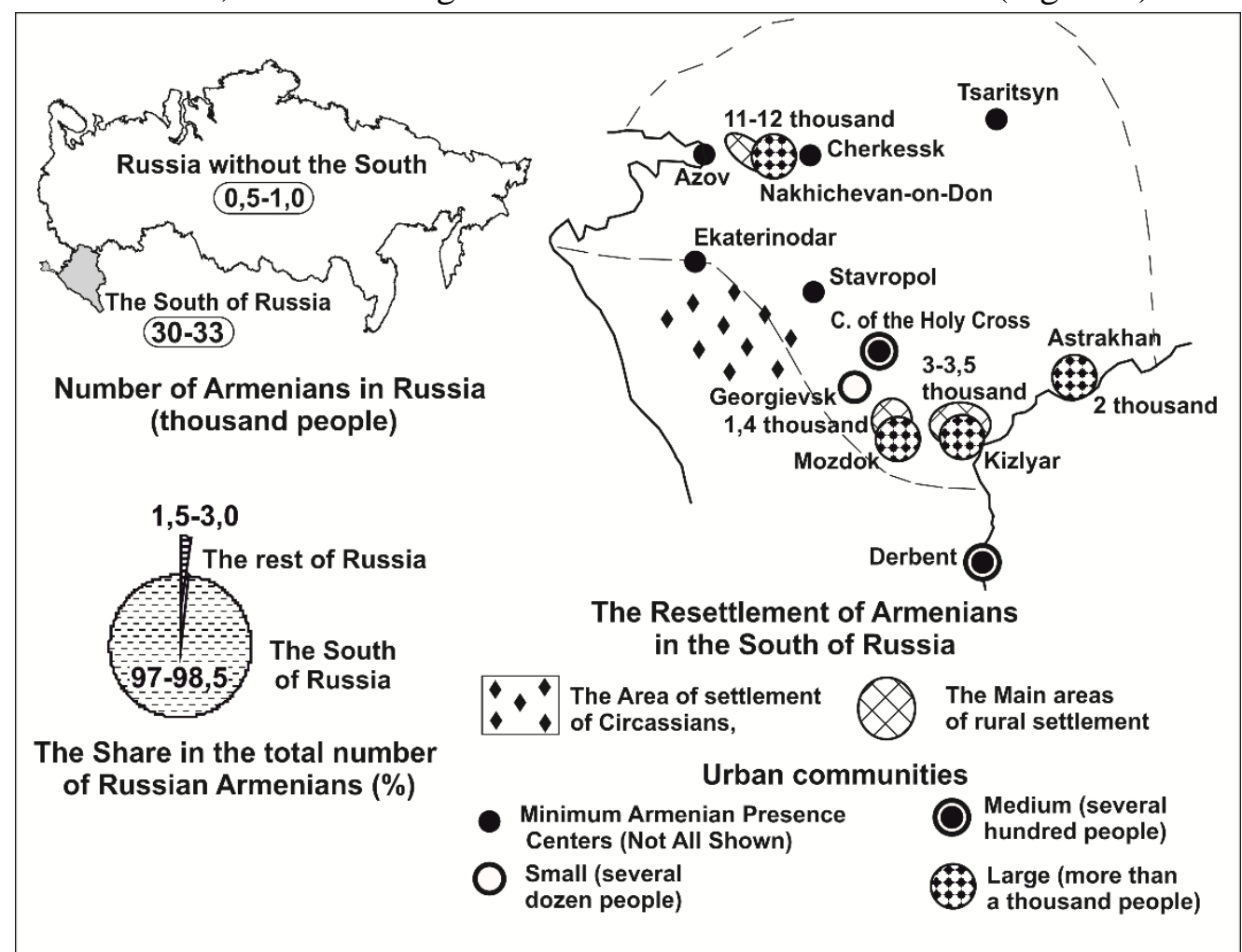

Figure 1. Armenians in Russia, 1800 ${ }^{1}$

Even 100 years later, at the end of the 19th century, the system of settlement of Armenians within Russia had barely changed, despite the fact that Transcaucasia, which had a large Armenian population, had become a part of the empire. But the Armenians almost never left this region. Outside it they were few, and they continued to be concentrated mainly in Novorossia, which at that time, in addition to the steppe of the Pre-Caucasus (Don, Kuban, and Stavropol), included the Black Sea provinces and Bessarabia. As a result, the South of Russia still accounted for more than 95\% of the Armenian population settled within the territorial borders of the modern Russian Federation (Figure 2).

\footnotetext{
${ }^{1}$ Maps compiled using data from (Avakov 2012; Aganesova, Suzdaltseva 2007; Hakobyan 2005; Arakelyan 1984; Volkova 1966; Cabuzan 1990, 1996; Ter-Sarkisyants 1998, 2005).
} 


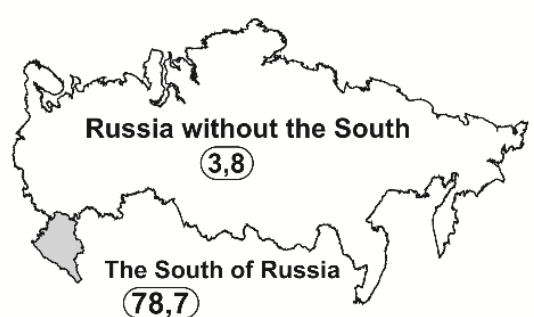

(78,7)

Number of Armenians in Russia (thousand people)

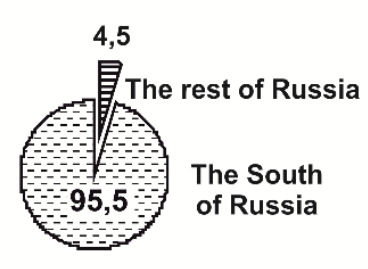

The Share in the total number of Russian Armenians (\%)

\section{Armenians by counties and districts} of South Russia

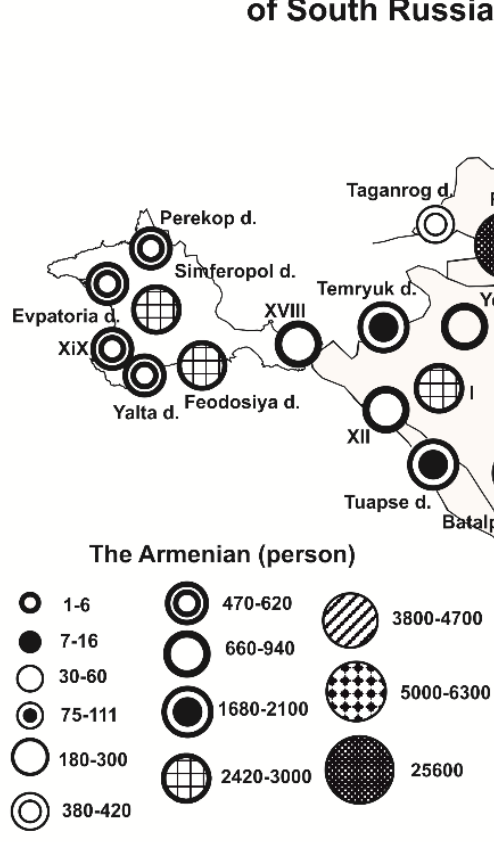

Figure 2. Armenians in Russia, $1897^{2}$

In the overwhelming majority of provinces of central, northern, or trans-Ural Russia, Armenians at the turn of the 20th century are extremely few. The first general census of the population of the empire in 1897 recorded their numbers here at 5-15 people per province. These small groups are distinguished by a very high level of urbanization by the standards of the time, and consist predominantly of men. In most provinces of the empire, the number of male Armenians was 3-4 times (sometimes 10-12 times) greater than the number of women. Given the minimal population sizes and gender imbalance, it's more likely that this is not a question of local

\footnotetext{
${ }^{2}$ Maps 2-3 and 5-17 use materials from the First General Census of the Russian Empire in 1897, as well as from the All-Union Censuses of 1926-1989 and the All-Russian Census 2002-2010. Geodemographic statistics of the Armenian population for 2002 and 2010 in Russian regions and urban centers were collected from the Rosstat website, and also, in part, from the sites of its regional offices. Electronic resources: 1897 census - URL: http://demoscope.ru/weekly/ssp/emp_lan_97_uezd.php; the 1926 census - URL: http://demoscope.ru/weekly/ssp/rus_nac_26.php?reg; 1939 census - URL: http://demoscope.ru/weekly/ssp/rus_nac_39.php; 1959 census - URL: http://demoscope.ru/weekly /ssp/rus_nac_59.php; 1970 census - URL: http://demoscope.ru/weekly/ssp/rus_nac_70.php; 1979 census - URL: http://demoscope.ru/weekly/ssp/rus_nac_79.php; 1989 census - URL: http://demoscope.ru /weekly/ssp/rus_nac_89.php; 2002 Census - URL: http://demoscope.ru/weekly/ssp/rus_nac_02.php; The 2010 Census - URL: http://demoscope.ru/weekly/ssp/rus_nac_10.php (access date: 03/14/2018).
} 
ethnic groups, but of a dispersed settlement, of a certain number of single men living in cities, mostly large, at the level of the provincial center.

Among the demographic centers of the Armenian population within central Russia can be singled out the communities of the two capitals, Moscow and St. Petersburg (Figure 3). However, at the turn of the twentieth century they too are several times smaller than the urban Armenian communities of many southern Russian cities (and St. Petersburg does not even fall into the top ten).

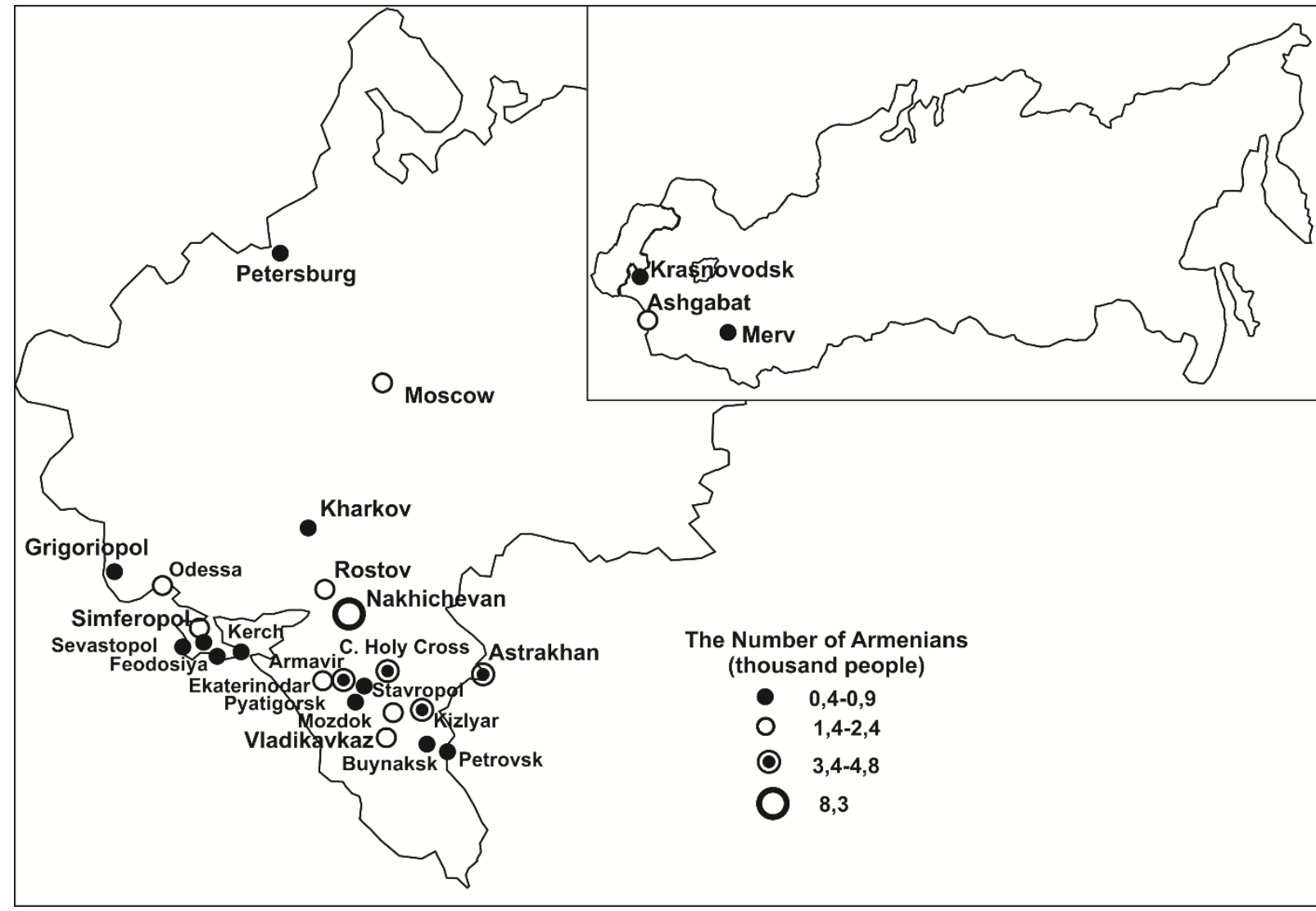

Figure 3. The largest urban communities of Armenians in the Russian Empire, 1897 (without Transcaucasia)

The beginning of the twentieth century, especially the period of the First World War, is a time of well-known tragic events for the entire Armenian people, which in geodemographic terms led to another cardinal change in their system of settlement. The genocide of 1915-1916, the mass migration of the following years and the collapse of the Ottoman Empire, which had lost a significant part of its territory, reduced the demographic potential of the Armenian population of Turkey by an order of magnitude. Within 15-20 years it ceased to be the main focus of the Armenian people. This role would be taken over by Soviet Russia, which in the early to mid-1920s had an Armenian population already several times greater than that of Turkey. (Figure 4). 


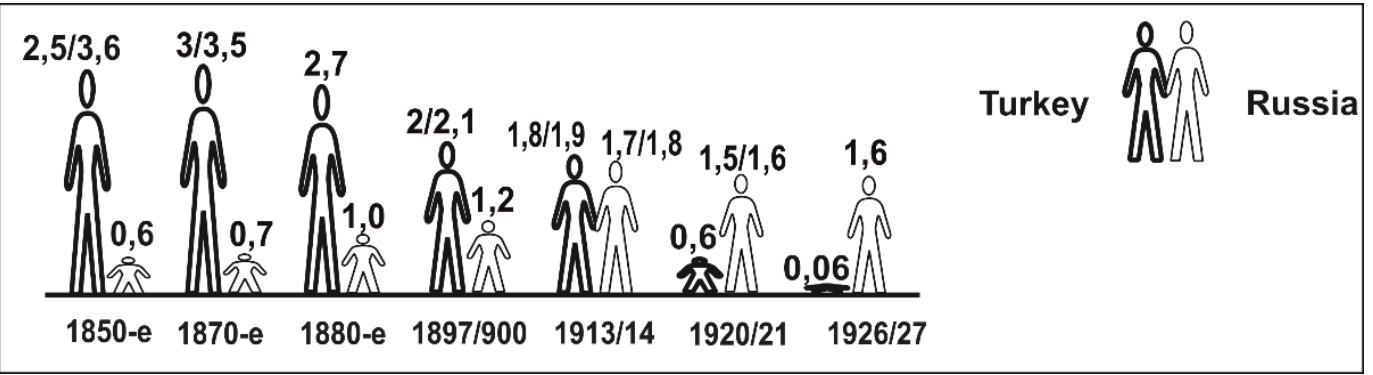

Figure 4. The dynamics of the Armenian population in the Ottoman Porte (Turkey) and in the Russian Empire (USSR), 1850s - 1920s, million3

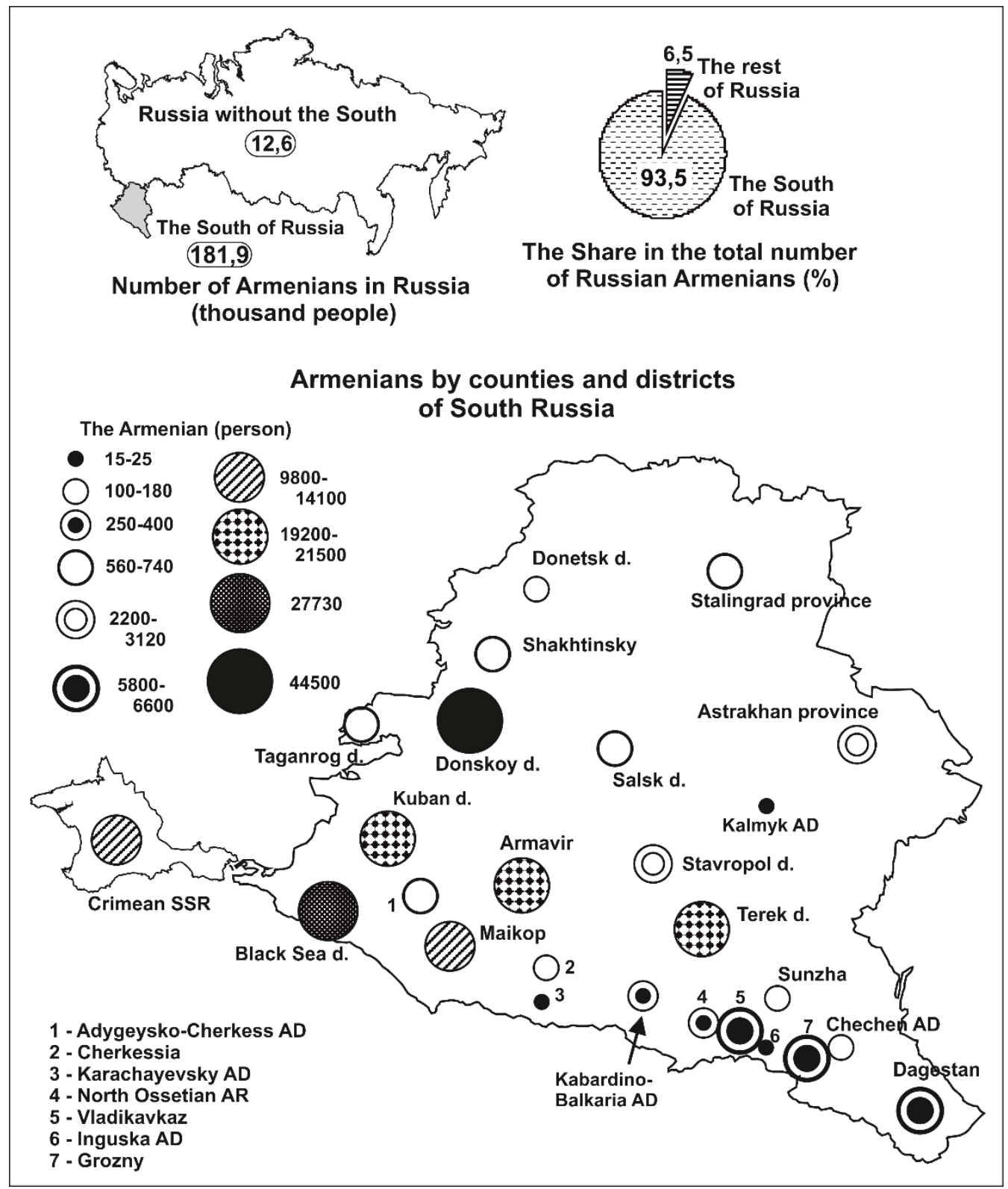

Figure 5. Armenians in Russia, 1926

The first region, however, to be filled with refugees and migrants in the late Russian Empire was Transcaucasia, followed, to a much lesser extent, by the South of Russia, within which by the

\footnotetext{
${ }^{3}$ Map compiled from data collected by G.G. Sargsyan (Armenians 2012: 81-87). 
end of the 19th century and the beginning of the 20th century only a few tens of thousands of migrants had settled. This migration wave almost never reached central Russia, especially its Trans-Ural regions. And although the total number of Russian Armenians almost tripled in the first quarter of the century, the census of 1926 (Figure 5) found almost the same geography as in the late 19th century. More than $95 \%$ of Armenians in Russia (within the present borders of the Russian Federation) were still residents of its southern macroregion.

The process of spatial decentralization of the settlement system of the Armenian population within the RSFSR becomes obvious only in the 1930s. By the end of this decade, its share outside the South increases by 3 times and exceeds $20 \%$ of the total number. The explanation would seem to be clear: the interregional migration that was rapidly growing during the first five-year periods and nationwide labor brigades led to the spatial circulation of Armenians too. This is partly true. The number of Armenians of the RSFSR outside its southern macroregion increased by 3.5 times in the period 1926-1939 (Figure 6). However, in the South itself, their number in this period decreased. In absolute terms, the reduction was insignificant, but taking into account the natural increase of the local Armenian population, the extent of its outflow might have reached 15-20\% (if not $25 \%$ ) of the total number of Armenians in the southern macroregion.

Thus, the migration circulation between Armenia and the RSFSR in the 1930s was complex. On the one hand, a part of the migrants who had settled in the South of Russia during the World War I and the Civil War now returned to their Soviet republic. Among them at this time were small groups of the titular population who moved to other republics of the USSR, including the RSFSR, and often to the most distant regions from the Caucasus.
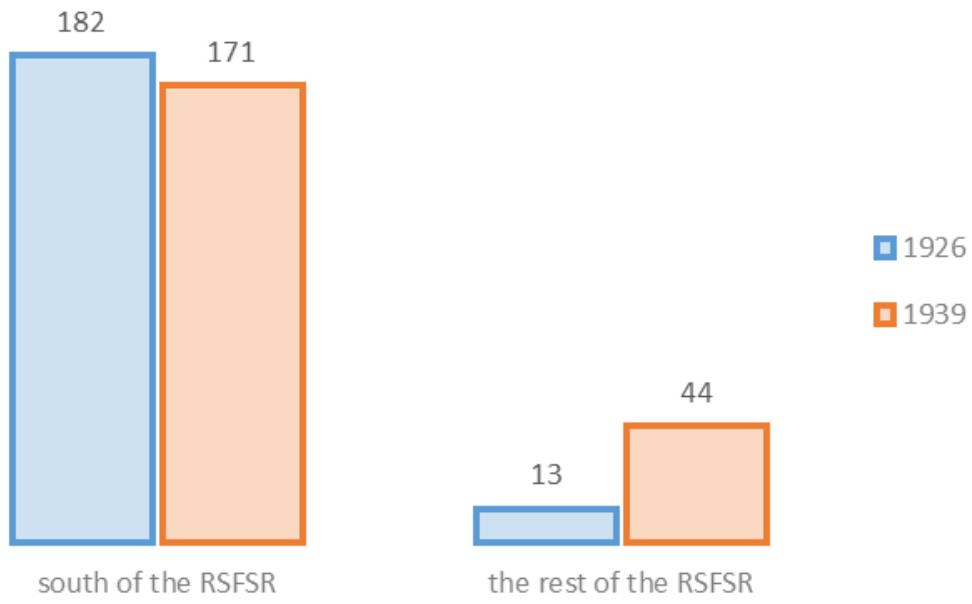

Figure 6. Dynamics of the Armenian population of the southern macroregion and the rest of the RSFSR, 1926-1939, thousand people

As a result, the size of the Armenian population in many Russian regions increased many times over. However, even this growth in the interwar period was not enough for the new regional groups of Armenians (they were still concentrated in the cities) to become large demographic centers comparable in size to the leading urban communities of southern Russia (Figure 7). 


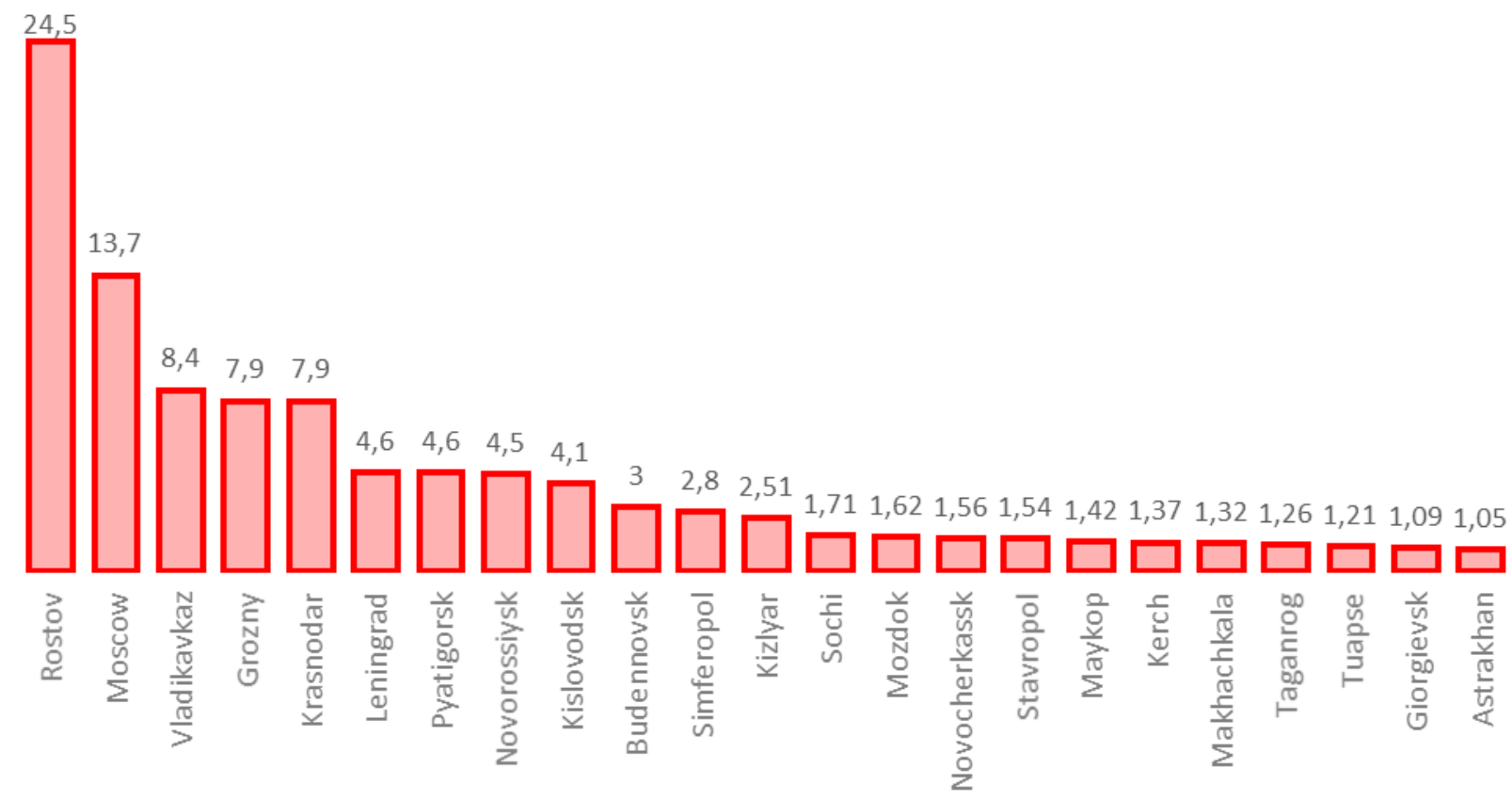

Figure 7. The size of the leading urban Armenian communities of the RSFSR, 1939, thousand people

In addition to an urban form of settlement, another sociodemographic feature of Russian Armenians is preserved - a significant gender imbalance. In most regions of greater Russia outside its southern territories, the Armenian population in the 1930s still consisted predominantly of men.

World War II had a dramatic impact on the geodemographic dynamics of the Armenian population of Russia. But the first post-war census of the population of the USSR was carried out only in 1959. 15 postwar years made up for the human losses suffered, masked shifts in the settlement system associated with the war and, in general, recorded some quantitative growth of the Armenian population of the RSFSR compared to the pre-war period (from 218,000 people in 1939 , it increased to 256,000 by the end of the 1950 s).

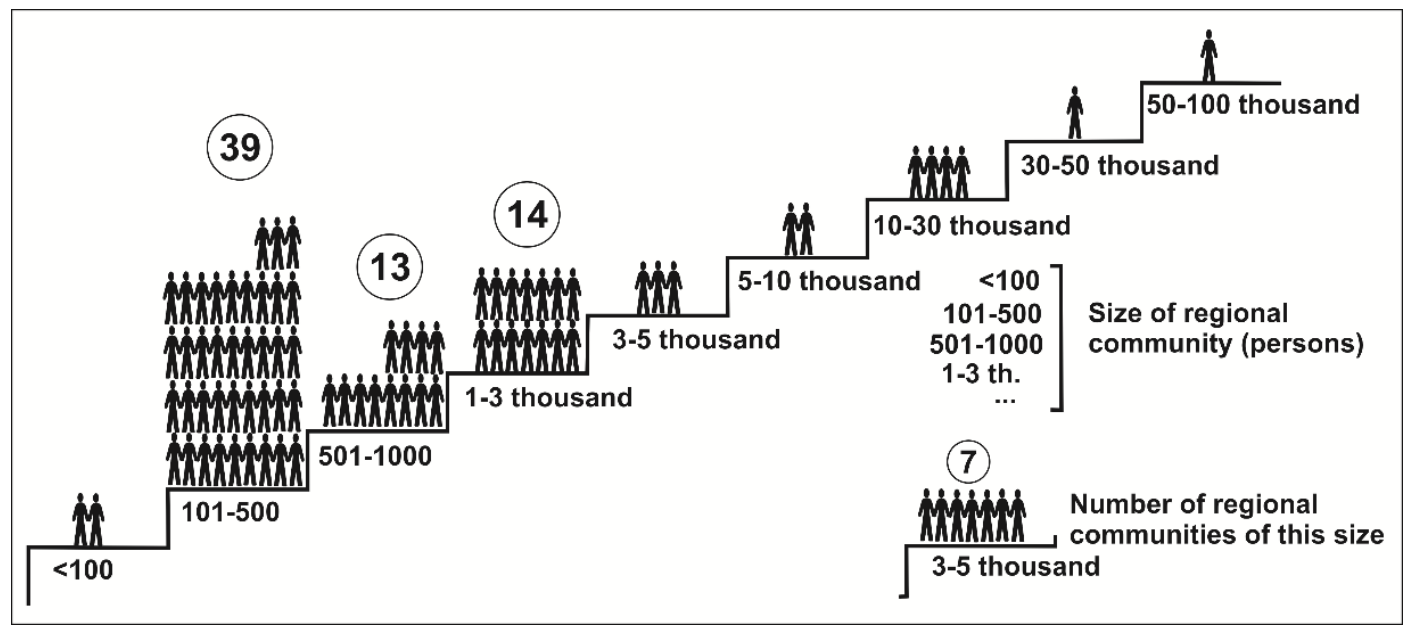

Figure 8. The size of the regional groups of the Armenian population in the RSFSR, 1959 


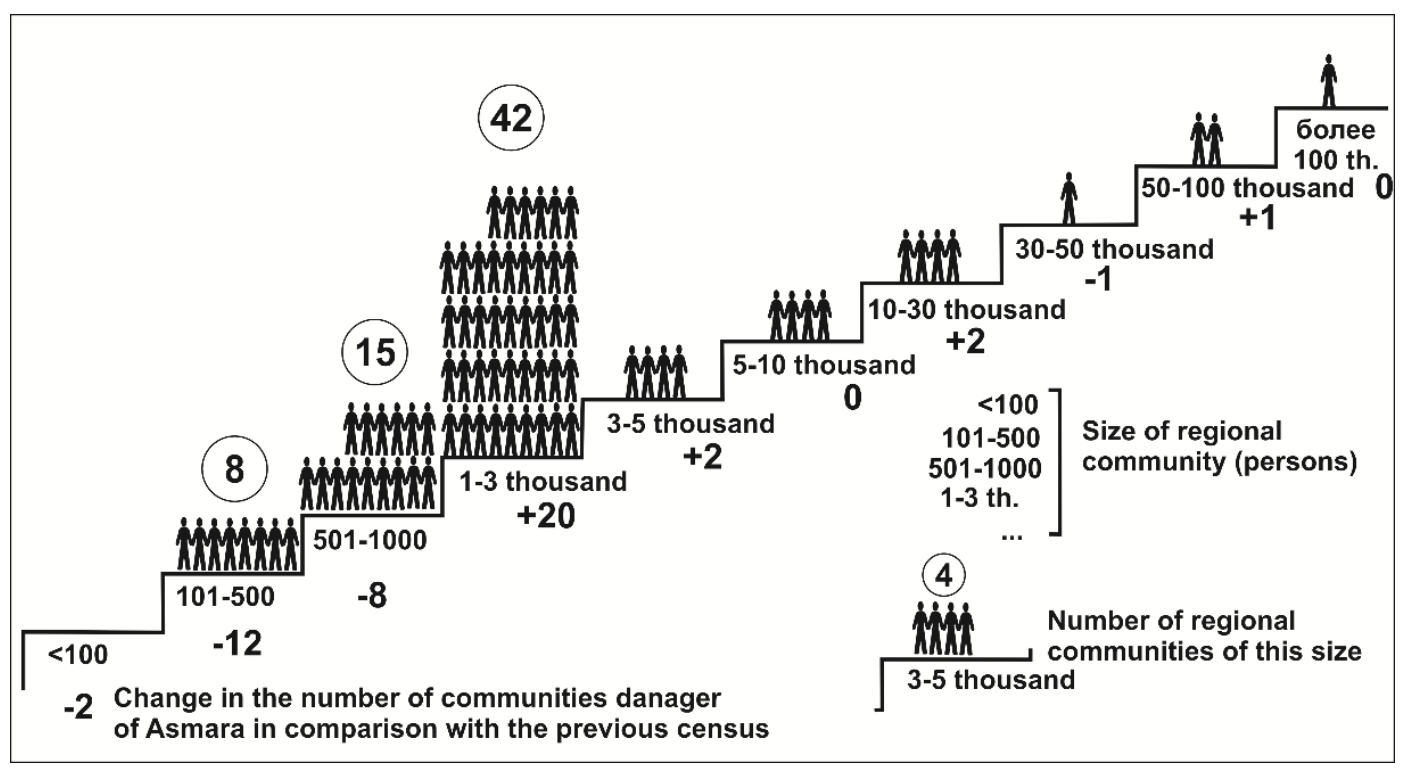

Figure 9. The size of the Armenian regional communities in the RSFSR, 1989

Henceforth, this upward demographic trend would not be interrupted. At the same time, communities in southern Russia and groups of Armenians in other macroregions of the RSFSR were growing in parallel. In spatial terms, this growth was almost ubiquitous. Moreover, if in 1959 the size of the majority of regional groups of Russian Armenians was in the range of 100-500 people, by the end of the 1980s they had risen to an average of 1-3 thousand (Figures 8-9). However, even such a significant quantitative growth for a long time turns out to be an insufficient condition for the transformation of this growing demographic set into a full-fledged network of territorial communities, as evidenced by the gender structure of most regional groups of Russian Armenians in 1970 (Figure 10).

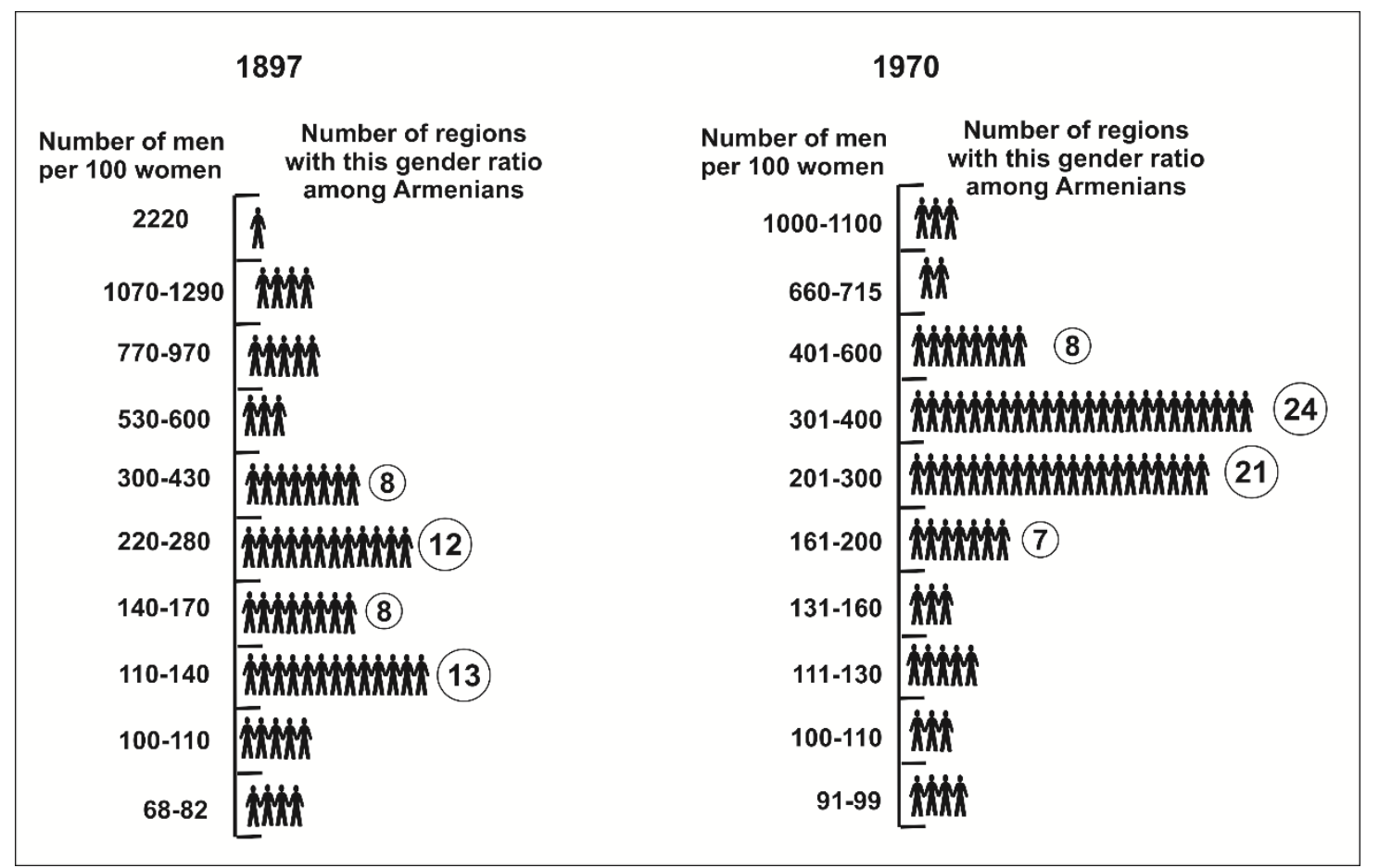

Figure 10. The level of gender balance in the Russian regional groups of the Armenian population, 1897, 1970 
In comparison with the start of the 20th century, the level of gender imbalance has changed little. By the beginning of the 1970s, territorial groups of Armenians with 2 to 4 times more men than women still predominated in Russia outside its southern macroregion. In other words, the Armenian population of greater Russia, as in the interwar period, was made up predominantly of single men of young and middle age - students of universities and technical schools, military personnel, labor migrants, various kinds of specialists on assignment. It is not surprising that such territorial ethnic groups very slowly transformed into full-fledged regional communities.

The situation changes significantly only in the last Soviet decade. The rapid quantitative growth of the migration of Armenians into the RSFSR, associated with the tragic events in the South Caucasus, the systemic crisis, and then the collapse of the Soviet Union, significantly increases the size of the Russian territorial groups. In 34 regions of Russia, the number of Armenians more than doubled in the 1980s; in another 28 it increased by 50-100\%. By the end of the Soviet period, in 58 Russian regions the Armenian population exceeded a thousand people (a decade earlier there were only 34 such regional groups; figure 11).

This migration wave, unlike the migrations of previous decades, was no longer so clearly tied to the urban system. The hasty nature of this resettlement flow, sometimes resembling an evacuation, forced new migrants to be modest in their demands. People fleeing from war and pogroms did not always have the material opportunities to settle in cities, where the cost of living was higher than in rural areas.

As a result, the level of urbanization of the Armenian population in the 1980s declined in almost 60 Russian regions, and in half of them it was very noticeable (by $10 \%$ or more). And the reduction in the share of citizens meant that the levels of the ethnic presence of Armenians in the urban and rural areas of the RSFSR, which were so noticeably different from the beginning to the middle of the 1970s, have now become significantly closer. For the most part, the forced nature of the Armenian migration of this time also determined major changes in the gender structure of the migrants. In contrast to the stable 1960s - 1970s, when mainly young single men went outside the Caucasus to study and seek work, the migration flow of the 1980s was made up primarily of families who were forced to leave their former place of residence forever.

Thus, the male advantage in the vast majority of Russian territorial groups declined. But most importantly, from a place of temporary residence (to get an education, earn money, pursue a profession) the regions of greater Russia began to turn into the new migrants' home, with all the ensuing consequences associated with the need to fit into the social environment that adopted them.

Plans and desires of forced migrants differed. Not all who came to the Russian "boondocks" intended to put down roots forever in the places where they had been brought as a result of a hasty departure from Transcaucasia. However, it was precisely the fact that they had landed in this new environment as full families which would often become the central factor ultimately determining their future and significantly accelerating their integration into the societies that had accepted them.

Thus, simultaneously in dozens of Russian regions begins a spontaneous process of transition from territorially dispersed groups of Armenians to regional communities (that is, 
the transformation of isolated, predominantly male urban groups with a rapidly changing composition into well-structured, gender-balanced communities with a high proportion of permanent residence). Such communities were much more disposed to internal cohesion and interaction.

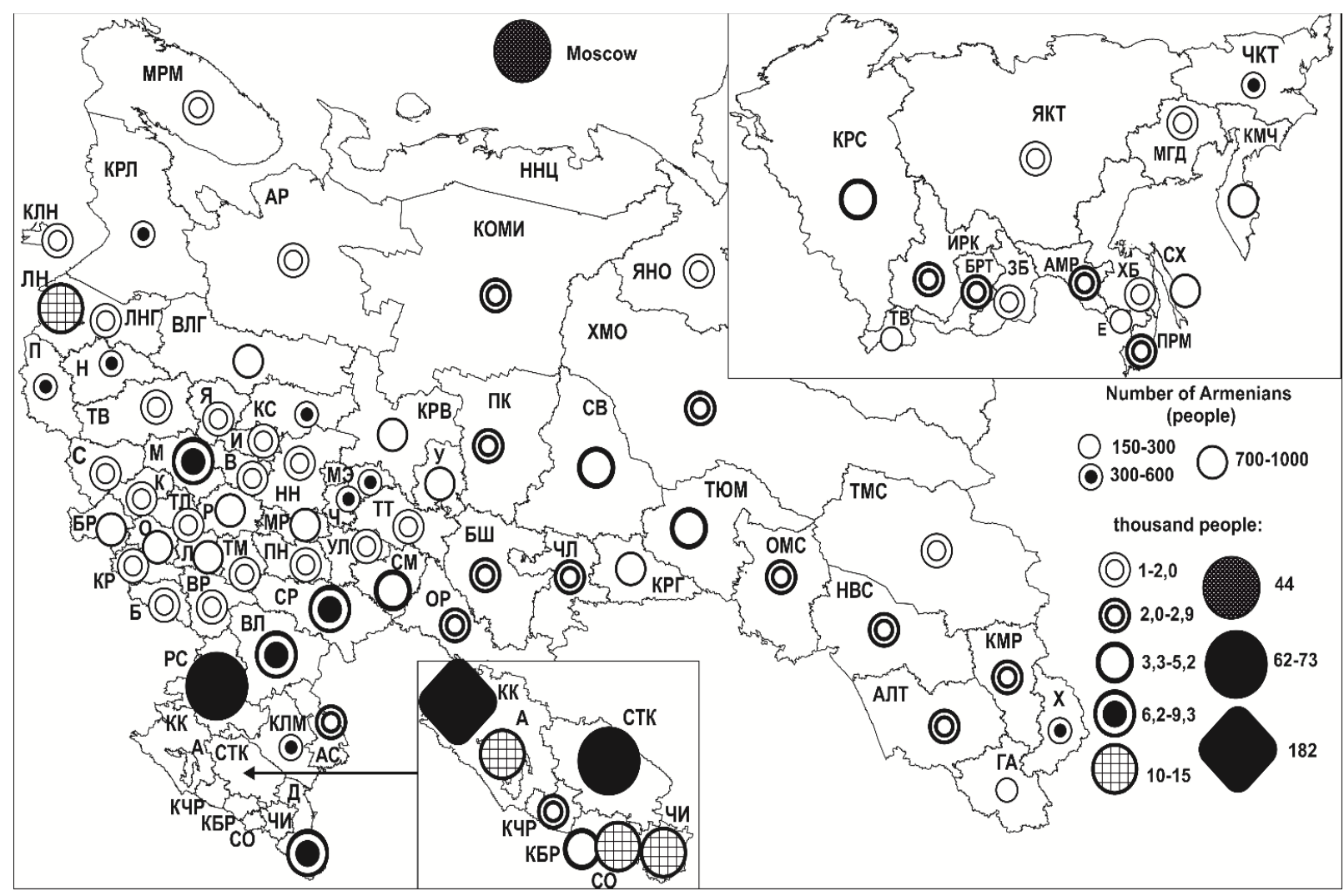

\section{Figure 11. Regional groups of the Armenian population in the regions of the RSFSR, 1989}

What we see is the acquisition of a new quality, which makes it possible to consider such territorial groups no longer just groups of people of the same nationality, but full-fledged regional communities. Again, individual elements of this systemic transition could be seen already in the social and geodemographic dynamics of Russian Armenians in the 1960s - 1970s. However, the sharp intensification of this process comes only in the mid- to late-1980s, and continues in the post-Soviet period (in a significant number of Russian regions this process is not fully completed even now, thus stretching out for many decades).

The first post-Soviet decade was associated with an even more impressive quantitative growth of the Armenian population of Russia. In 1989-2002 it increased from 0.53 million to 1.14 million people, allowing Armenians to rise eight positions in the demographic ranking of the peoples of the Russian Federation (from 15th to 7th).

In almost three dozen regions of the Russian Federation the growth of territorial groups in the 1990s was more than threefold; in another 26 the number of Armenians grew 2-3 times. In absolute figures, as one would expect, the greatest numbers went to the southern Russian regions, mainly the three leading communities of the Pre-Caucasus (Kuban, Stavropol and Don), whose total population grew by almost a quarter of a million people. 
However, for the first time ever the combined demographic growth of the Armenian population of other macroregions of Russia was higher. In 1989-2002 the number of Armenians in the Russian Federation outside its southern macroregion more than tripled (from 167 thousand to 514 thousand). Thus, in parallel with the perceptible expansion of the geography of the Armenian people in Russia, a significant territorial "re-centering" of its settlement system took place.

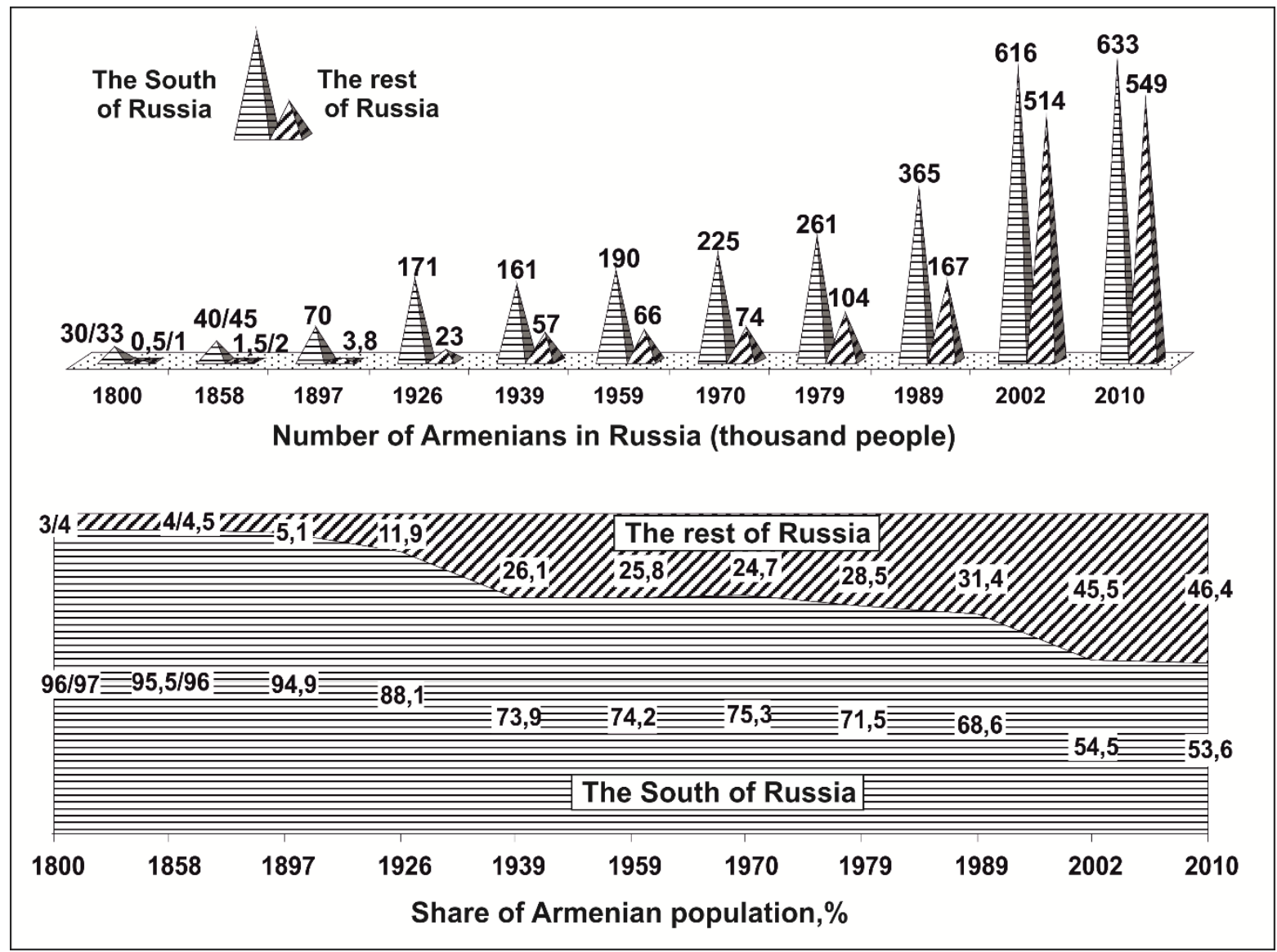

Figure 12. The ratio of the Armenian population of the southern macroregion to the rest of Russia, 1800-2010 4

Despite retaining an obvious demographic superiority over other territories, the South of Russia saw the degree of its dominance markedly shrink, now including only a little more than half of all Russian Armenians (Figure 12). On the other hand, central Russia and the Volga region saw their own relative importance increase significantly: the cumulative share of the Armenian communities of the two federal districts (Central and Volga) grew over 1989-2002 from 18.6 to $29.5 \%$. The share of the Ural and Siberian territorial groups increased in the general structure.

Such a rapid demographic growth of the Russian diaspora made possible a significant increase in the proportional representation of Armenians not only in hundreds of cities of the country, but also in vast rural areas. The gender balance continued to improve: the bulk of the migrant flow which spread throughout the Russian provinces consisted of complete families,

\footnotetext{
${ }^{4}$ Data for the South of Russia are shown without the Armenians of Crimea, and therefore differ somewhat from the indicators in Figures 1-2, 5.
} 
which radically changed the age and gender structure of the local territorial groups of the Armenian population.

The first decade of the 21 st century is a period of a certain quantitative stabilization and spatial optimization of the Russian Diaspora of Armenians, linked to the intra- and interregional flow of a part of post-Soviet migrants. In the years 2002-2010 the number of Armenians in the Russian Federation, according to the results of the last Russian census, grew by only $4.6 \%$. However, a detailed analysis of their geodemographic dynamics during this period suggests that some members of the diaspora were not taken into account by the last census.

According to our calculations, the most probable size of the Armenian population of the Russian Federation in 2010 could be $1.35-1.45$ million (that is, 15-23\% more than recorded by the census). In other words, in terms of their demographic potential, the Armenians were quite comparable to the Chuvash and Chechens, who at that time were in 5th and 6th place in the ranking of the largest peoples of Russia, respectively.

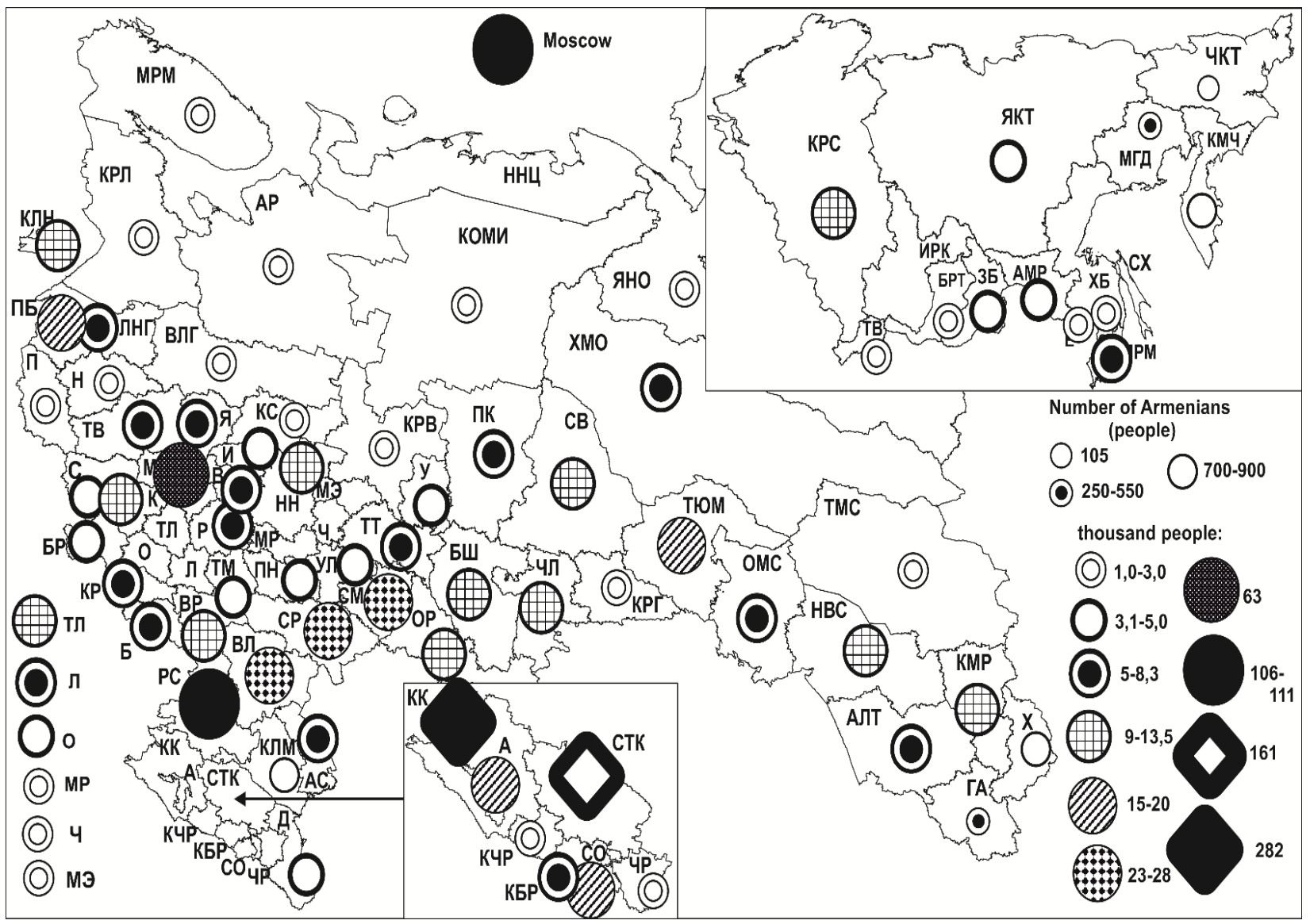

Figure 13. Regional groups of the Armenian population in the regions of Russia, 2010

However, this assumption does not contradict the conclusion made earlier about the gradual quantitative and spatial stabilization of the Armenian diaspora of the Russian Federation at the beginning of the 21st century, the growth rates of which in any case dropped significantly. The 2000s are a time of internal optimization of the new system of Armenian settlement that had taken shape during the period of their rapid and spontaneous demographic growth. Settling into the Russian regions that had accepted them, the immigrants begin looking for more comfortable and acceptable centers (districts) of residence and employment. There is a more or less intense 
inter- and intra-regional flow of the Armenian population. The last census recorded a decrease in the number of Armenians in 28 regions of the Russian Federation, and a significant increase (by more than 20\%) only in 14 (in 12 more regions the Armenian population grew by 10-20\%).

It is obvious that the resources for further spatial expansion of the settlement system of Armenians within Russia, if not exhausted, are rather small. The most acceptable/comfortable territories of the country in terms of climate, culture and socio-economics have already been demographically settled by the diaspora. Further significant expansion of this ethnic geography is unlikely, and all other changes in it (in particular, inter-regional demographic "re-centering") will remain slow and gradual.

An illustration of such "gradualness" is the more than once mentioned trend toward the further territorial decentralization of the diaspora, a reduction in the demographic weight of the southern Russian communities. This trend continued into the 2000s. However, for 2002-2010 the share of the South of Russia in the total number of Russian Armenians decreased by less than $1 \%$ (from 54.5 to 53.6\%). Three of the four largest regional communities of more than 100 thousand people still belong to the South of Russia (Krasnodar and Stavropol Territories, Rostov Oblast), as do all the six regions in which Armenians make up more than $1 \%$ of the local population.

But the aughts saw a new activization of another long-term trend - the rapid demographic growth of the capital community ${ }^{5}$. The total number of Russian Armenians living in Moscow and the region increased in the period between the censuses from 135 thousand to 170 thousand (an increase of $26 \%$ versus $5 \%$ for the entire Russian diaspora). There also appeared another geodemographic feature. For the first time in the entire history of the development of the Moscow community, the Moscow region came to the fore, with the number of Armenians there growing by $60 \%$ in the 2000s (the maximum figure among all Russian regions). Obviously, we are talking about the rapid formation of yet another (after that in the south of the Russian Federation) major demographic center of the settlement system of Russian Armenians. And there is every reason to believe that this process will continue, which means that not only the number, but also the proportion of "capital" Armenians will continue to increase in Russia at a faster pace (in 19892010 alone it grew from 10 to $14.4 \%$ ).

Parallel to this, the post-Soviet period saw a significant increase in the share of Armenians in the Volga region (from 4.9 to $9.1 \%$ ) and in the Central Federal District (from 3.4 to 8.5\%). Thus, the decentralization of the settlement system of the Russian Armenian diaspora continued, interconnected with the demographic growth of a significant number of previously peripheral territorial groups. This process was directly connected with an increase in the proportion of Armenians in the ethnic structure of their regions. If, in 1989, there were 40 regions in the Russian Federation in which the share of Armenians was less than $0.1 \%$ of the local population, then by 2010 there were only two of them left (the Chechen Republic and Ingushetia).

\footnotetext{
${ }^{5}$ Which already in the 1970s had finally become the largest urban community of Russian Armenians, ahead of the Armenian population of Rostov and Nakhichevan-on-Don, which had been the largest for almost two centuries (these centers were united in the early 1920s)
} 


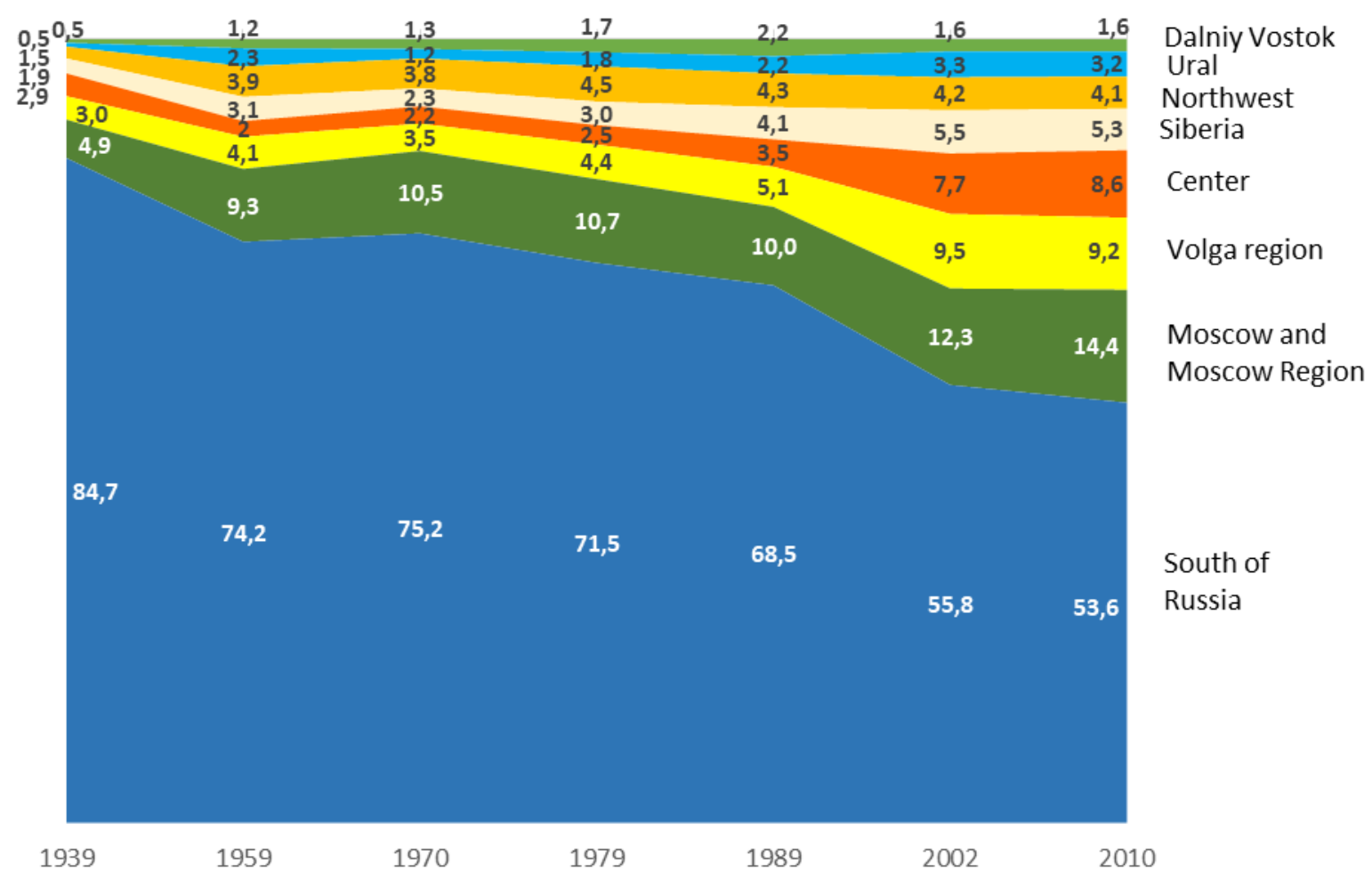

Figure 14. The share of macroregions in the distribution of the Armenian population of Russia, 1939-2010, \%

But more important for the settling in of the territorial groups of Armenians in the host regional societies were their internal optimization and, above all, the further reduction of gender imbalance. If, in 1989, in 37 Russian regions there were over two times more men than women in the structure of the local Armenian population, in 2010 there were only 3 such regions left (Figure 15). At the same time, the number of communities with a balanced gender structure (gender ratio 1: 1-1.2) increased from 8 to 13 - evidence of a gradual increase in the systemic sustainability of the territorial groups of the Armenian population of Russia.

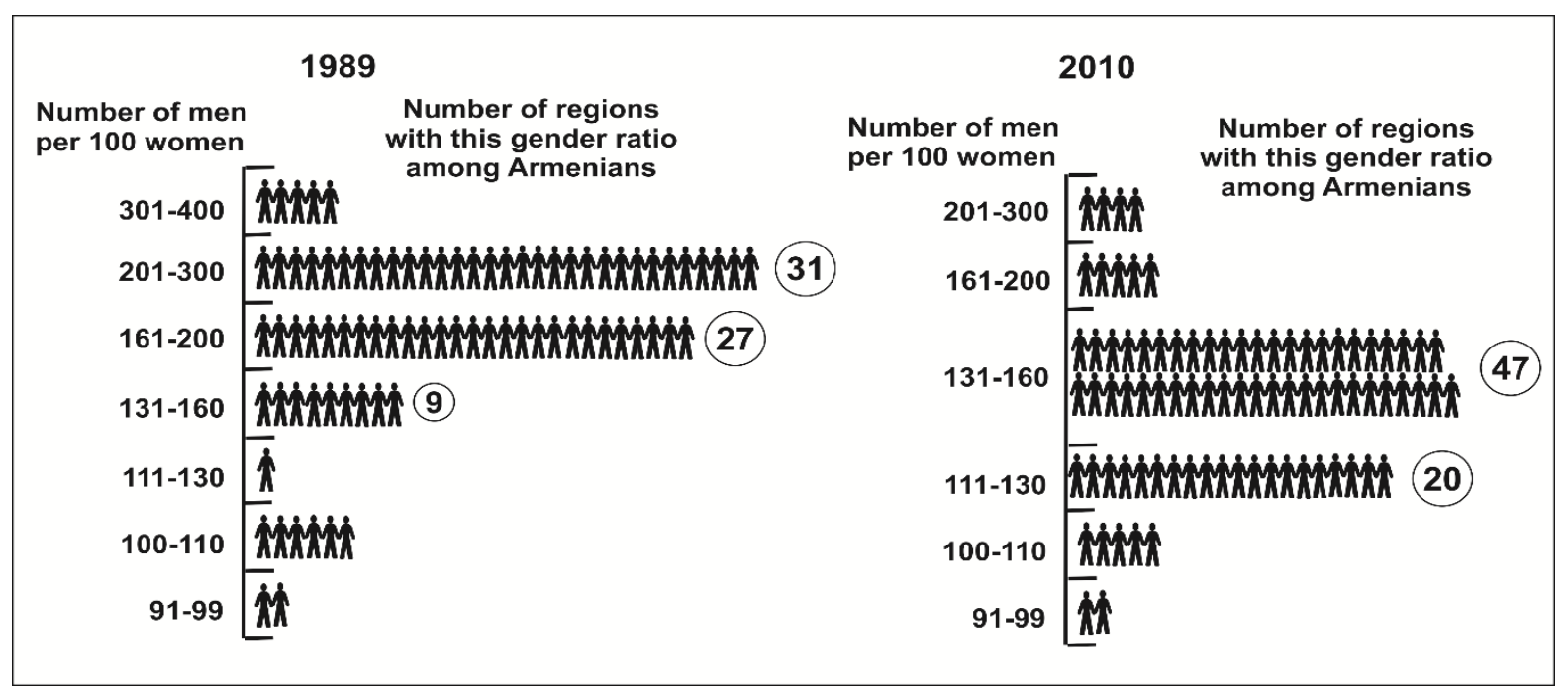

Figure 15. The level of gender balance in the Russian regional groups of the Armenian population, 1989-2010 
Rural migration, which grew significantly in the post-Soviet period, reduced the overall level of urbanization of Armenians in Russia. In 2010, at 69\% it was lower than that of the entire population of the Russian Federation (73.7\%). But it is significant that in 70 regions of the Russian Federation the share of citizens among representatives of local Armenian communities exceeded the region-wide indicators of urbanization of the population. This is not surprising, given the demographic "boom" of many Armenian urban communities, primarily those belonging to the administrative capitals of the regions. In 1989-2010 the number of such communities of more than a thousand people in Russia increased 2.4 times (from 48 to 115). Moreover, most of them appeared outside the southern macroregion. And for the first time in the history of the Russian diaspora, the total number of Armenian urban communities in greater Russia surpassed their number in the South of the country (61 vs. 53; Figure 16).

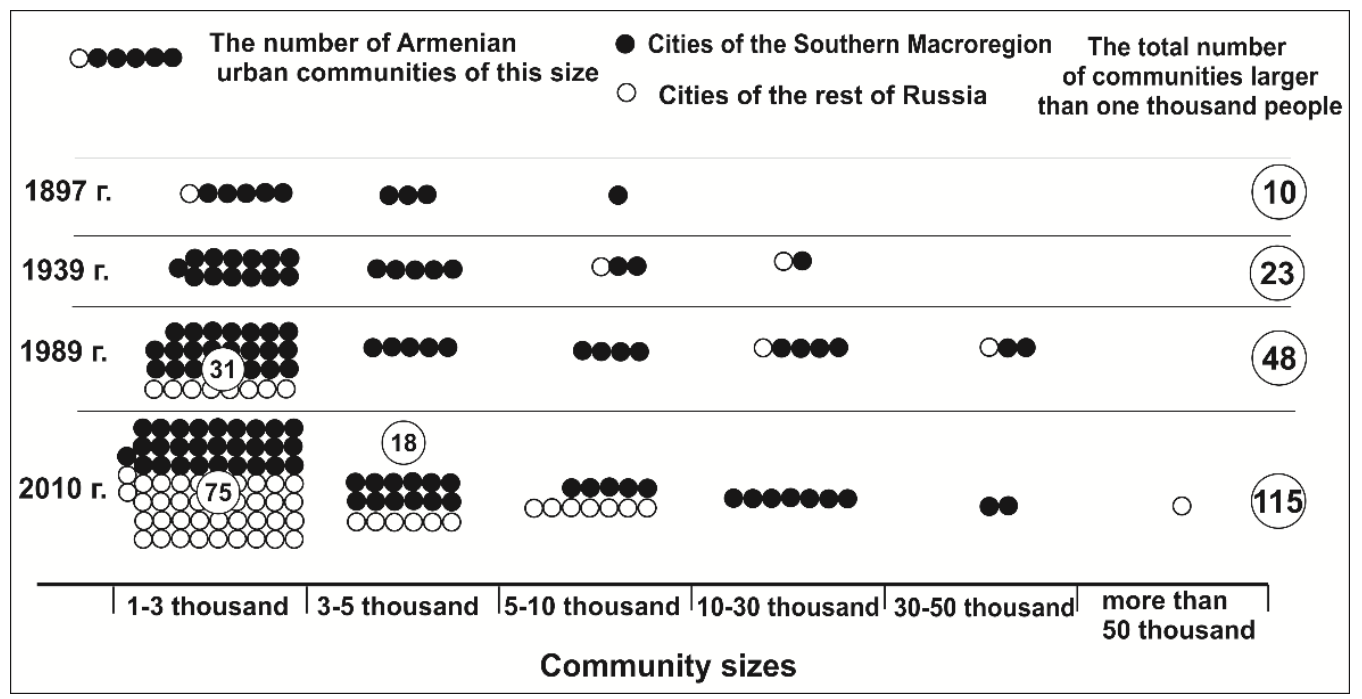

Figure 16. Dynamics of the number of large (more than a thousand people) urban communities of Russian Armenians, 1897-2010

\section{CONCLUSIONS}

So, the "new" history of the Armenian diaspora in Russia, which began in the Petersburg period, has not only continued for three centuries, but in recent decades has reached a higher systemic level, characterized not only by a rapidly growing demographic potential (Figure 17) and wide geography, but also by a significantly higher level of internal organization of most of its regional centers. The Armenian diaspora in Russia entered the $21^{\text {st }}$ century on a systemic rise in all spheres of its activity, laying a solid foundation for positive geodemographic dynamics for the entire foreseeable future.

The present study makes it possible in a first approximation to distinguish three major periods in the geodemographic history of Russian Armenians, differing in their total number in Russia, the breadth of their geography and other central socio-demographic characteristics (including the form of settlement, level of urbanization, gender ratio; figure 18). 


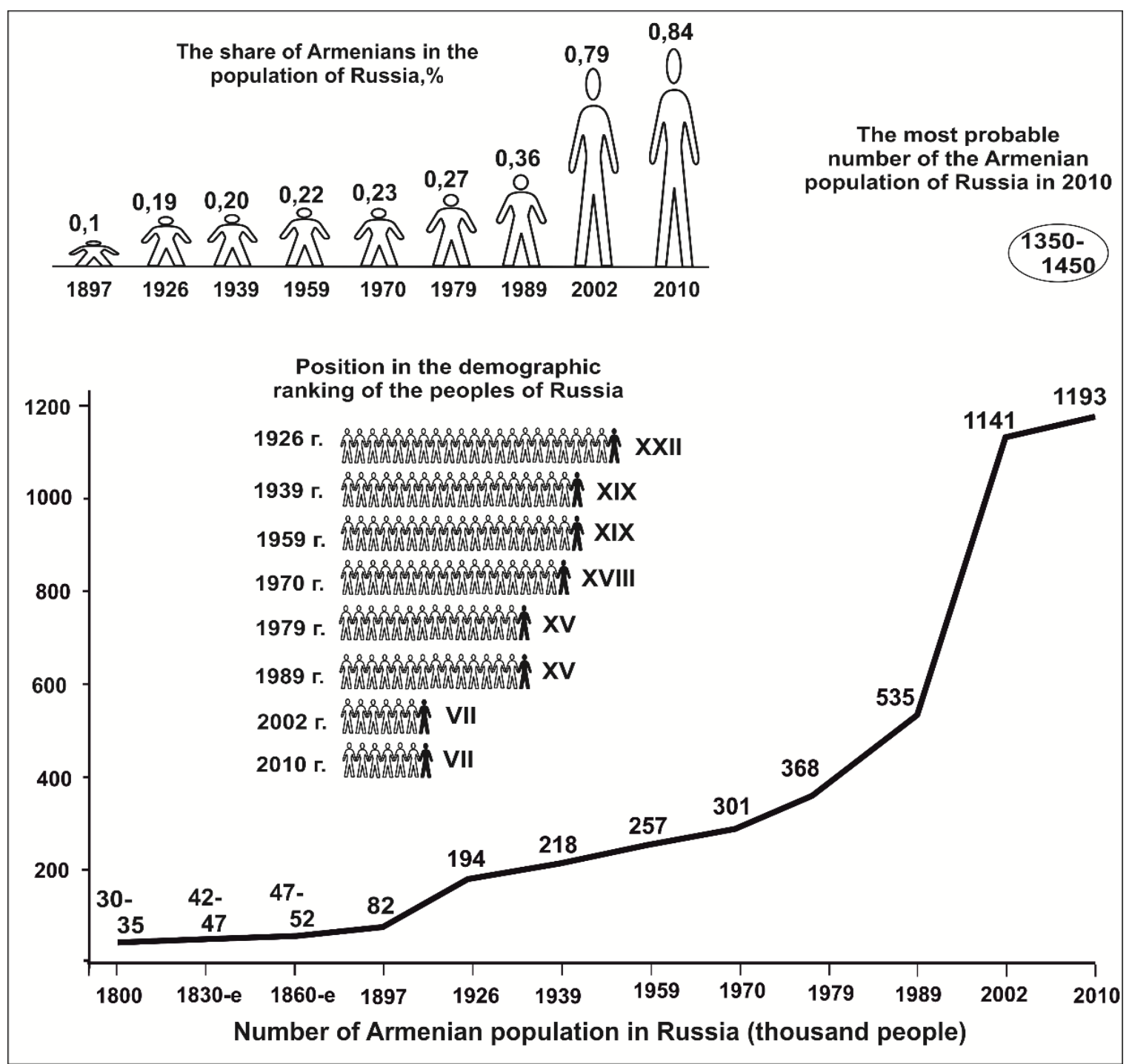

Figure 17. Dynamics of the Armenian population of Russia, 1800-2010

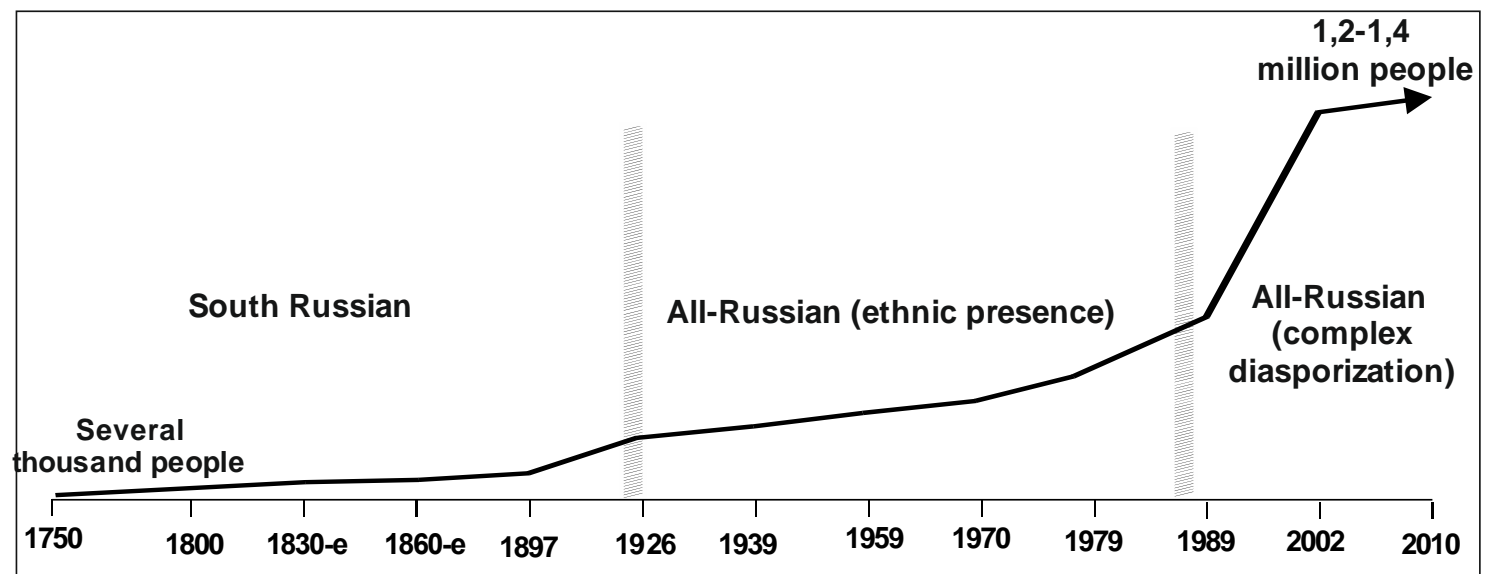

Figure 18. The major periods of historical phases of geodemographic dynamics of the

\section{Armenian diaspora of Russia}

The first of these periods can be defined as "South Russian". Its beginning dates back to the second third of the 18th century and is associated with the emergence in the south of Russia of a number of large regional communities / colonies. This period was the longest, stretching to the second quarter of the twentieth century. Throughout its duration, the vast majority of the Armenian 
population of Russia (in its modern spatial contours) was concentrated within the southern macroregion, and even more precisely in the steppe of the Pre-Caucasus (the lower Don, Kuban, Stavropol). Throughout the rest of Russia, the presence of Armenians at this time remains minimal (if you do not take into account the communities in the two capitals, but here too it is very limited in size).

Thus, the central characteristics of this period include:

- maximum concentration (95\% or more of the total) of Russian Armenians within the boundaries of the steppe of the Pre-Caucasus and other territories of the South of Russia;

- progressive quantitative growth and the gradual expansion of the geography of the Armenians within this macroregion;

- active participation of local communities in the process of regional urbanization, in the economic and cultural life of the southern macroregion; a high level of urbanization of most of the territorial groups of the South and a balanced gender structure;

- minimal presence of Armenians outside the South of Russia, represented in other macroregions of the country by "loners" or local groups of several people, consisting mainly of men concentrated in large cities.

The second period of the geodemographic dynamics of Russian Armenians can be conditionally designated as a stage of an "All-Russian ethnic presence". This stage almost completely coincided with the Soviet era, ending in the mid-1980s. Its main socio-geographical features are:

- a gradual increase in the number of regional groups of the Armenian population outside the South of Russia and the expansion of their all-Russian geography;

- growth of the aggregate demographic potential of Armenians in greater Russia (and their share in the structure of the local population), with the greatest numbers still remaining in the communities of the southern macroregion;

- a high level of urbanization of the majority of Russian regional groups;

- an unsustainable composition (constant population "rotation") and a significant (often by many times) preponderance of men in the territorial groups of Armenians outside of southern Russia are factors determining the low level of rootedness of these groups in the main areas of life of regional societies;

- a low level of internal co-organization and weak development of group (community) social structures in most Russian regional groups, which at the time do not represent diasporas / communities in the full sense of this concept. 


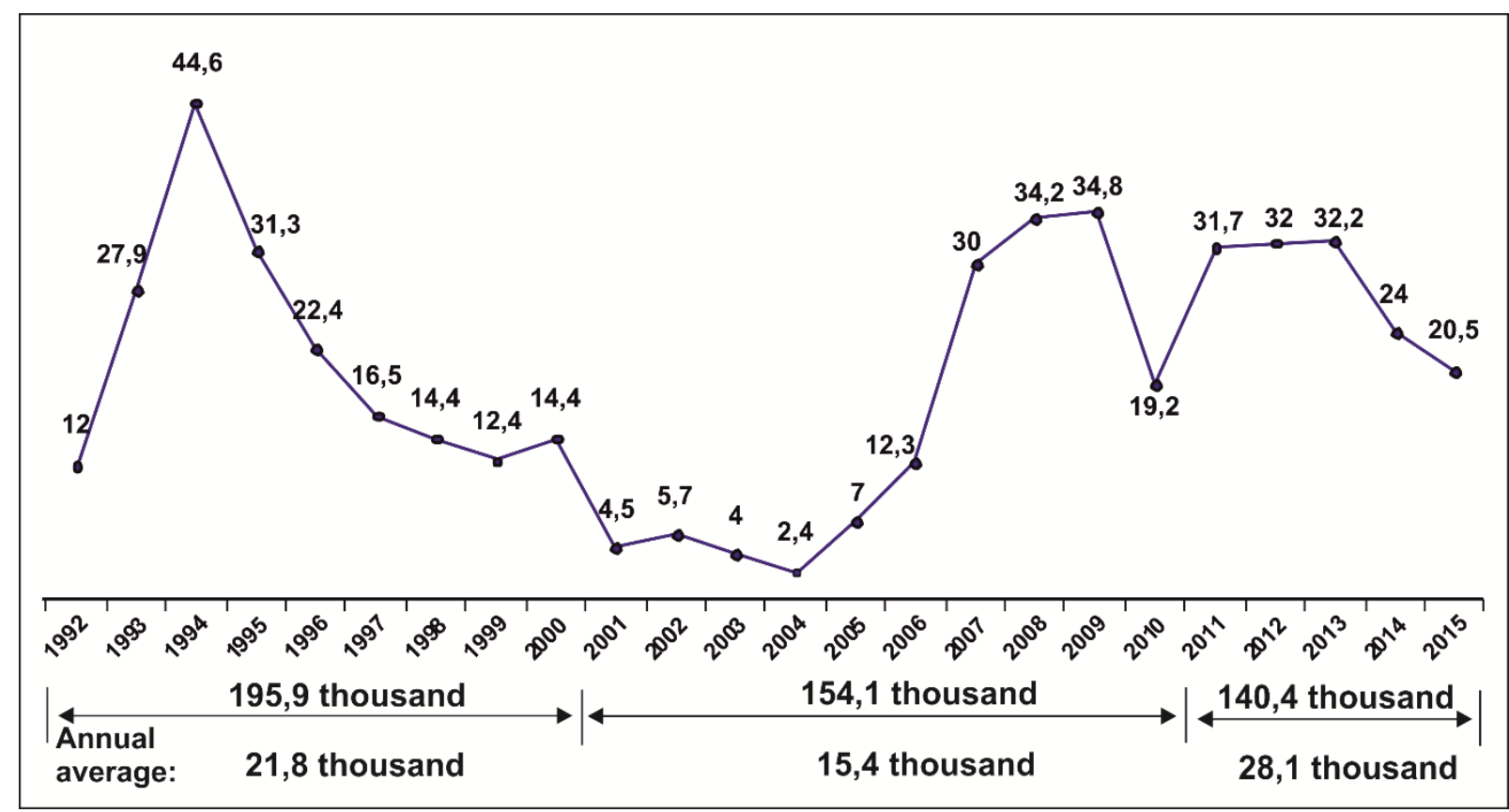

\section{Figure 19. Net inflow of population (migration balance) from Armenia to Russia, 1992-2015, thousand ${ }^{6}$}

The third period begins in the mid-late 1980s and can be defined as a period of "All-Russian integrated diasporization" of the Armenian population of the Russian Federation. It is characterized by rapid quantitative growth and spatial expansion of the diaspora, a correction of gender imbalance (a reduction of male preponderance) and active socio-economic and sociocultural rooting of Armenians in dozens of Russian regions.

The main sociodemographic features of this period include:

- rapid demographic growth and rapid spatial expansion of the majority of regional groups of the Armenian population of the Russian Federation;

- rapid rates of geodemographic dynamics of Armenians in greater Russia, increasing decentralization of the settlement system of the Russian diaspora and a noticeable reduction in the demographic share of the communities of the southern macroregion;

- a significant decrease in the level of male quantitative dominance in most regional groups and a significant increase, in territorial communities, in the number of families and permanent residents;

- rapid growth in many Russian regions of the number and share of rural Armenians, which made it possible to significantly increase the indicator of their ethnic presence in the Russian rural "boondocks";

- active formation of community social structures and institutions; the transformation of many dispersed territorial groups of the Armenian population into well-structured regional communities;

- comprehensive integration of communities into the life cycles of host territorial societies, their socio-political, economic and cultural life;

\footnotetext{
${ }^{6}$ The figure uses data from (Demographic Yearbook ... 2001, 2006, 2012, 2017).
} 
- rapid growth of the aggregate socio-economic potential of territorial communities; greater representation in all high-status professional communities and corporate hierarchies of their regions.

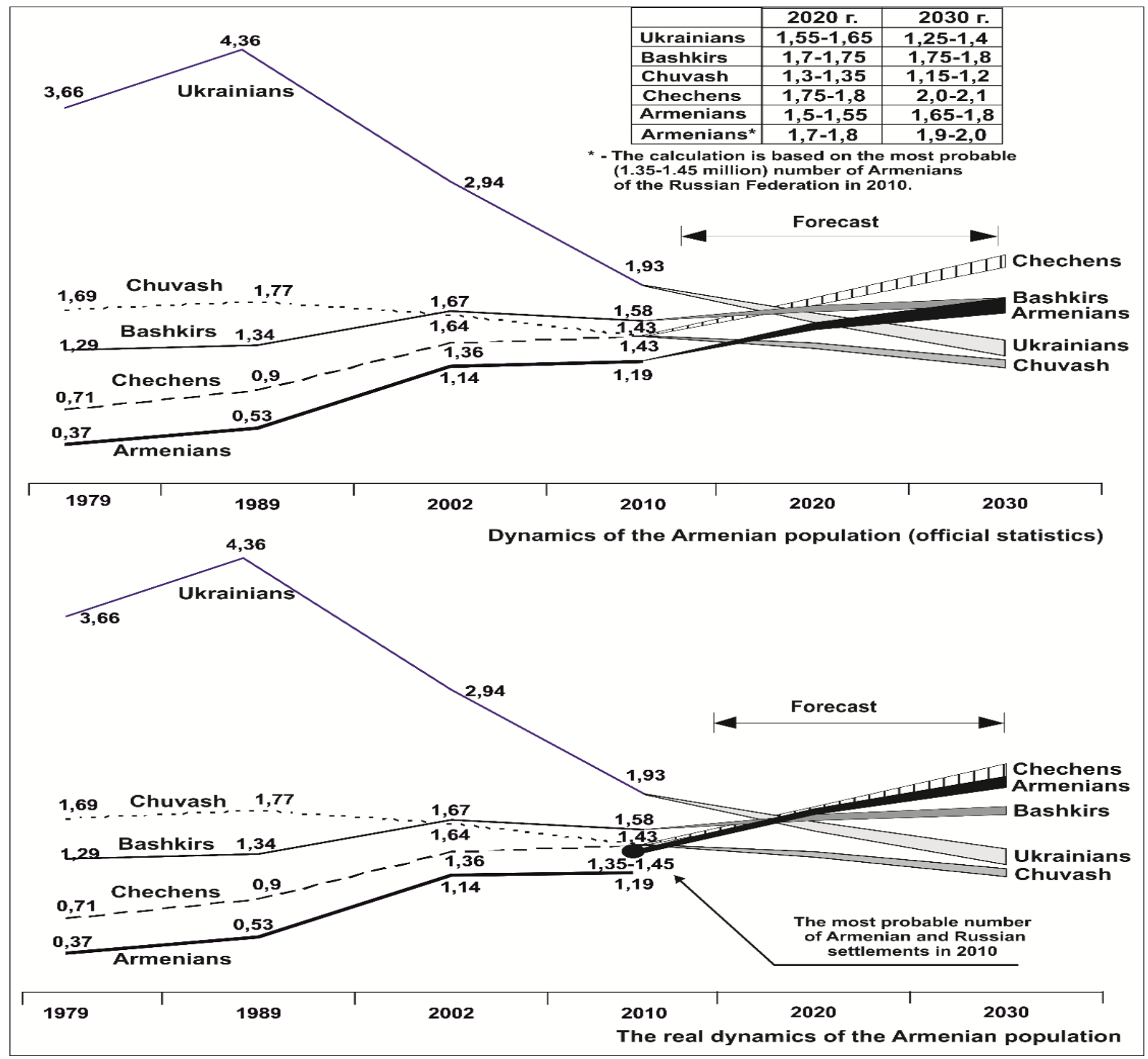

Figure 20. The most likely scenarios for the quantitative dynamics of a number of leading peoples of the Russian Federation in the short (2020) and medium (2030) term, millions

The stage of active diasporization of the Russian Armenians is not yet complete, and will, by all appearances, require quite a bit more time. However, this systemic transformation is not directly related to the demographic dynamics of the community, which depends on three factors: natural increase (decline), the direction and activity of migration processes and, finally, the scale of assimilation.

Given the existing parameters of the natural dynamics of the Armenian population of the Russian Federation (depending on the region, either simple reproduction or minimal growth), as well as stable migration replenishment and a limited extent of assimilation losses, there is every reason to predict further quantitative growth of the Armenian diaspora in Russia. 


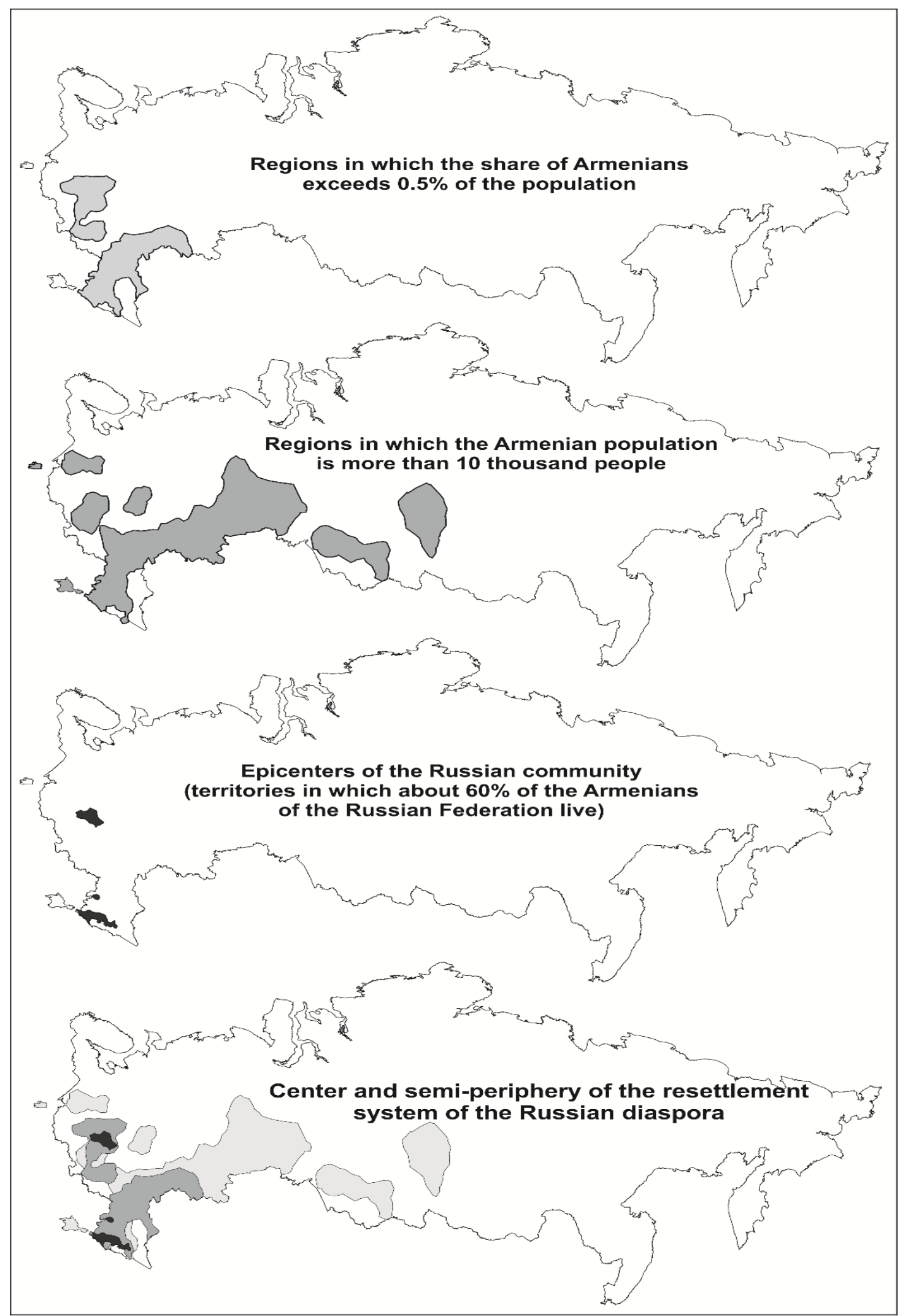

Figure 21. The central zones of the settlement system of Armenians of Russia

Even in the "official" demographic ranking of the peoples of the Russian Federation, Armenians in the current decade are likely to move up two places and enter the top five largest national communities of Russia (Figure 20). This will happen even if the hidden demographic component of the Armenian community does not come out of the shadow during the next two 
censuses. If this component is taken into account, then Russian Armenians, whose numbers by 2030 could reach 1.85-1.95 million, become real contenders for a place among the top three largest peoples of Russia, after Russians and Tatars. In any case, their demographic indicator will be very close to those of the Chechens and Bashkirs, primarily to the former.

At the same time, there is little reason to expect noticeable changes in spatial terms - the geography of the central places of the Russian diaspora has generally taken shape already. The south of Russia (the steppe of the Pre-Caucasus), together with the metropolitan region (Moscow and the region) that joined it in recent decades, now account for about $60 \%$ of Russian Armenians, and will remain the leading centers for the foreseeable future (Figure 21).

\section{REFERENCES}

Aganesova D.V., I.A. Suzdal'tseva (2007). Armyanskie obshchiny Dagestana v XVIII - nachale XIX vv. [Armenian communities of Dagestan in the XVIII - early XIX centuries].

Makhachkala. 244 p.

Akopyan V.Z. (2005). Kratkiy ocherk po istorii armyanskikh poseleniy na Yuge Rossii [A short essay on the history of Armenian settlements in the South of Russia]. Pyatigorsk: PGLU. URL: http://armeniansite.ru/istoriya-armyanskikh-poselenij-rossii/4-istoriya-armyanskikhposelenij-na-yuge-rossii.html (accessed: 18.02.2018).

Arakelyan G.S. (1984). Cherkesogai (istoriko-etnograficheskoe issledovanie) [Cherkessogai (historical and ethnographic study)] // Kavkaz i Vizantiya [Caucasus and Byzantium]. Issue. 4. Yerevan: 43-130.

Armyane [The Armenians] (2012). Narody i kul'tury [Peoples and cultures] / L.M. Vardanyan, G.S. Sarksyan, A.Ye. Ter-Sarkisyants, eds. Moscow: Nauka. 648 p.

Avakov P.A. (2012). Armyane na Donu v XVII-XVIII vv. (do 1779 g.) [Armenians on the Don in the XVII-XVIII centuries (before 1779)] // Armyane Yuga Rossii: istoriya, kul'tura, obshchee budushchee [Armenians of the South of Russia: history, culture, common future]. Rostov-on-Don: Izdatel'stvo YUNTS RAN: 120-125.

Demograficheskiy ezhegodnik Rossii 2001 [Demographic yearbook of Russia 2001] (2001). Moscow: Goskomstat: 336-339.

Demograficheskiy ezhegodnik Rossii 2006 [Demographic yearbook of Russia 2006] (2006). Moscow: Goskomstat: 469-470.

Demograficheskiy ezhegodnik Rossii 2012 [Demographic yearbook of Russia 2012] (2012). Moscow: Goskomstat: 452-455.

Demograficheskiy ezhegodnik Rossii 2017 [Demographic yearbook of Russia 2017] (2017). Moscow: Goskomstat: 210-212.

Kabuzan V.M. (1990). Narody Rossii v XVIII veke. Chislennost' i etnicheskiy sostav [Peoples of Russia in the XVIII century. Number and ethnic composition]. Moscow: Nauka. 256 p.

Kabuzan V.M. (1996). Naselenie Severnogo Kavkaza v XIX-XX vekakh [The population of the North Caucasus in the XIX-XX centuries]. St. Petersburg: Blits. 224 p.

Ter-Sarkisyants A.Ye. (1998). Armyane - istoriya i etnokul'turnye traditsii [Armenians - history and ethno-cultural traditions]. Moscow: Vostochnaya literatura: 397 p. 
Ter-Sarkisyants A.Ye. (2005). Istoriya i kul'tura armyanskogo naroda s drevneyshikh vremen do nachala XIX veka [History and culture of the Armenian people from ancient times to the beginning of the nineteenth century]. Moscow: Vostochnaya literatura. $686 \mathrm{p}$.

Volkova N.G. (1966). O rasselenii armyan na Severnom Kavkaze do nachala XX veka [On the resettlement of Armenians in the North Caucasus before the beginning of the XX century] // Istoriko-filologicheskiy zhurnal [Historical and Philological Journal]. 3: 259-264. 